\title{
THE ROLES OF ENVIRONMENTAL CONCERN, GREEN PERCEIVED VALUE, SUBJECTIVE NORMS, AND GREEN TRUST TOWARDS GREEN HOTEL PURCHASE INTENTION
}

\author{
Marsya R. Chairunnisa ${ }^{1}$ \\ ${ }^{1}$ Department of Management, Diponegoro University \\ marsya.nisa@gmail.com \\ Mirwan Surya Perdhana ${ }^{2 *}$ \\ ${ }^{2}$ Department of Management, Diponegoro University \\ mirwan@live.undip.ac.id
}

*Corresponding Author: mirwan@live.undip.ac.id

\begin{abstract}
With the continuous growth of the world economy, many companies believe that generating profit is vital for its sustainability. However, the profits were obtained without having consideration about any other factors such as environmental problems. At present, the earth is currently being hit by a lot of environmental problems such as global warming and climate change that was mainly caused by the human behavior with the purpose of developing their business. With that, a study of human behavior to help the earth is needed. The purpose of this study is to develop a framework to explore the influences of Environmental Concern, Green Perceived Value, Subjective Norms, And Green Trust on Green Hotel Purchase Intention. This research employs an empirical study by means of the questionnaire survey method to verify the hypotheses and to explore its managerial implications. Finally, this research offers several practical implications for developing successful businesses in Green service industry.
\end{abstract}

Keywords: Environmental Concern, Green Perceived Value, Subjective Norms, Green Trust, Green Hotel, Purchase Intention

\section{INTRODUCTION}

At the present time, many companies believe that generating profit is vital for its sustainability. In many cases, profits were obtained without having thoughts about any other factors such as environmental problems and so on. As what Shireman \& Kiuchi (2002) said, in today's economy, profits are obtained by extracting natural resources. 
However, as the economy grows, nature shrinks. Therefore, every benefit gained is a loss for the earth. Often what is called profit does not mean creating profit in the true sense but rather a reduction of gain for the future generation. This shows that the current development is unsustainable development.

With the continuous development in the world economy, the earth is currently being hit by a lot of environmental problems whether in the form of land pollution, water pollution and also air pollution. Climate change and global warming are the impacts that have been felt by the society in recent years. However, this can be solved by the presence of green technologies and innovations that develop in almost all of the existing business sectors, namely green products and green services. Green products are defined as products that are produced using toxic-free ingredients and with environmentally friendly procedures (Gurău \& Ranchhod, 2005). Whereas green services are the provision of services aimed at improving the welfare of natural ecosystems in the framework of "to improve the quality of life of the people of today and future generations" (Ostrom et al., 2010). That being said, green service is not only reducing the environmental impact of consumption, but also focusing on increasing environmental benefits. When scarcity of natural resources on the earth are extreme, green services increase natural ecosystem resources to protect humanity, who are the consumers of economic activities on earth.

Several studies have been conducted to understand the intention of consumers to visit environmentally friendly hotels. For instance, Teng (2011), Eze and Ndubisi (2013), and Jiang (2015) have investigated about the desire of individuals to visit environmentally friendly hotels and their reasons for doing so. However, most research was carried out in developed countries such as the United States and South Korea or in small but economically wealthy countries in Asia such as Taiwan and Malaysia. There has been no research focusing on green hotels in Indonesia yet.

There also have been many studies which identify factors influencing green purchasing intention in certain countries, however the research sample is based on citizen in general without identifying specific group of people. In this study, the younger generation will be chosen. The young generation here is a generation who likes to socialize and express themselves, is agile, and communicates digitally. Therefore, they are a very smart generation because the information that they get came from many sources. With that, the younger generation is the right target to find out how a company can determine which marketing segments they can target in the future.

The Objective of this research is aimed at exploring factors which influence individuals in using a green service. The paper begins by providing theoretical background of the relevant literature. Thereafter the methodology and the results from the quantitative study will be presented. The paper concludes with a discussion of the results, limitations and directions for future research.

\section{LITERATURE REVIEW}

Green Purchase Intention 
Purchase intention can be defined as the likelihood of a consumer's purchase decision to buy a product (Dodds et al., 1991; Grewal et al., 1998) or to visit a store offering services (Shao et al., 2004), a decision that came from the value and benefits perceived by consumers (Zeithaml, 1988). Purchase intention has always been treated as an important variable, and is extensively used in marketing academic literature because it is a good proxy of consumers' actual purchase behavior (Chandon et al., 2005; Fishbein and Ajzen, 1975; Schiffman and Kanuk, 2000). The evaluations of consumers' purchase intention can help practitioners both know better the trend of the market and adjust the position of products or services. The term Green purchase intention applies to the domain of environmental issues, means the likelihood of a consumer's purchase decision to buy an eco-friendly product which has a low impact on the environment. Consumers know that he/she is contributing to the environmental cause.

\section{Environmental Concern}

There is currently no stable and consensual definition of environmental concern (Le Borgne et al., 2015), which is a concept that carries a wide array of attitudes about environmental issues. These differences in definitions, and thus in measures, may explain the contradictory results on the relationship between environmental concern and travel behavior. According to $\mathrm{Hu}$ et al. (2010). Environmental Concern refers to people's awareness of the environmental issues and their willingness and support to resolve them.

Chen and Tung (2014) identified Environmental Concern as an important variable which influences Purchase Intention. Scholars working within the ecological domain propel the notion that environmental concern specifically motivates environmental purchase intentions towards hybrid-electric vehicles (Li et al., 2013) and green energy brands (Hartmann and Apaolaza-lbáñez, 2012). Hartmann \& Apaolaza-lbáñez (2012) noted that environmental concern positively impacts the intention to buy green-branded energy. Li et al. (2013) further proved the positive relation between the purchase intention of hybrid-electric cars and consumers' environmental concern. Similarly, Lin and Huang (2012) indicate that consumers with high environmental concern support and purchase green items more.

\section{Green Perceived Value}

Perceived value is defined as a consumer's overall evaluation of the net benefit of a product or service based on a consumer's appraisal (Bolton and Drew, 1991; Patterson and Spreng, 1997). Because environmental consciousness is more prevalent nowadays, this study proposes a novel construct, "green perceived value", and refers to Patterson and Spreng (1997) to define it as a consumer's overall appraisal of the net benefit of a product or service between what is received and what is given based on the consumer's environmental desires, sustainable expectations, and green needs. 
Numerous past literatures have indicated that perceived value was a discriminate component that influences purchase intentions (Hsu \& Lin, 2015); Ponte et al., 2015; Chen et al., 2012).

\section{Subjective Norms}

Subjective norms is a social factor which refers to perceived social pressure toward performance or non-performance of a particular behavior (Ajzen, 1991). Positive perception of significant others like friends, family, peers and relatives toward green products has been reported in prior studies to have a significant influence on green purchase intention of an individual (Dean et al., 2012; Teng et al., 2014).

Subjective norms relate to the perceived social influences/pressures to indulge or not to indulge in a given behavior (Ajzen, 1991; Buckley et al., 2007). Subjective norms reveal the beliefs of individuals about how they would be viewed by their reference groups if they perform a certain behavior. Past studies have indicated that attitude is significantly related with subjective norms. Chang (1998), Shimp \& Kavas (1984), Vallerand et al. (1992) and Tarkiainen \& Sundqvist (2005) have found in their studies that there exists a significant causal path between subjective norms and attitude leading toward behavior (purchase intention).

\section{Green Trust}

Green trust is a will to depend on a product, service or brand for a basic belief or expectation produced from credibility, goodwill, skills in environmental performance (Elsa and Alamsyah, 2013). In reviewing trust to environmentally friendly products, it can be studied through environmental reputation on this product and it is generally trusted, environmental performance is generally reliable, environmental claims can be trusted, environmental awareness of this product fulfills to expectation, and product promises and committed to protecting the environment (Chen and Chang, 2012). Past literature posits that customer trust is a determinant of consumer purchase intentions (Schlosser et al., 2006).

\section{Hypotheses}

Based on the previously cited theoretical and empirical literatures, the following hypotheses referring to the attitudes towards the environment and green products were proposed.

Hypothesis 1: Environmental Concern has a significant effect on Green Service Purchase Intention

Hypothesis 2: Subjective norm significantly influence Green Service Purchase Intention

Hypothesis 3: Green Perceived Value significantly influence Green Service Purchase Intention 
Hypothesis 4: Green Trust significantly influence Green Service Purchase Intention

\section{RESEARCH METHOD \\ Research Instruments}

The authors developed the survey based on previous scientific literature. This study uses ten-point Likert scales from 1 to 10 (rating from strongly disagree to strongly agree) to measure the items of the constructs. In order to ensure that the respondents have the same understanding of the survey that they will take, the authors represent an explanation of the factors which influence green hotel purchase intention in the survey's preface.

In order to measure Green Purchase Intention, five items were adapted from Lee et al. (2010). Three items based on Chen (2010) were used to measure green trust. Five items from Chen dan Chang (2012) were used for the measurement of Green Perceived value. Three items by Kim dan Choi (2005) to measure Environmental concern. And also, four items referring to Han et al. (2010) dan Chen et al. (2011) to measure Subjective norms.

In order to obtain reliable information from the respondents, established and validated scales were selected for data collection. Table 1 indicates the validity of each items to be used for further testing. Validity test is done in order to measure the validity of the questionnaire. Measuring validity of the items could be done by seeing the result of $r$ value and $r$ table. If $r$ value $>r$ table and is positive, then the item is declared as valid. Table 2 indicated the reliability levels obtained in this study for several factors toward green service purchase intention. Schuessler (1971) stated that a scale is considered reliable if it has an alpha value greater than 0.60 . Hair et al. (1998) added that reliability estimates between 0.60 and 0.70 represent the lower limit of acceptability in quantitative research studies. Due to the exploratory nature of this research, alpha value greater than 0.60 for reliability estimates is considered adequate.

\section{Data Collection and Characteristics of Respondents}

The questionnaires for this study were administered to 150 students from several big institution in Indonesia. According to Ferber (1977) using students as a sample is considered valid for exploratory studies. Furthermore, students are representing the new generation of consumers in the future. The respondents of this research consist of both sexes and are students pursuing their educational degree. The survey participants consisted of $49 \%$ males and $51 \%$ females. The majority of the survey respondents were educated with $92 \%$ pursuing bachelor's degree and the other $8 \%$ pursuing their master's degree. All of the respondents were students by profession which came from middle to high class category family. And additionally, the age of all of the survey participants were 
younger than the age of 25 years old. A total of 106 completed the questionnaires were obtained and deemed sufficiently complete to be useable.

\section{DATA ANALYSIS AND DISCUSSIONS}

Instruments test needs to be done in order to meet the accuracy and correctness must go through two requirements, which are validity test and reliability test. The results of the validity calculation use a comparison between $r$ value and $r$ table by looking at the corrected item total correlation column with the help of SPSS software. The item in question is valid if it has a calculated $r$ value $>0.191$ and it could be seen from table 1 . The Cronbach alpha for each factor was shown in Table 2. And the result shows that cronbach alpha for all the four factors were greater than 0.6 which means that the scale scores for each of the dimensions were reasonably reliable (Hair et al., 1998).

Table 1. Result of Validity Test

\begin{tabular}{cccc}
\hline $\begin{array}{c}\text { No. Item } \\
\text { Questions }\end{array}$ & $\mathbf{r}_{\text {value }}$ & $\mathbf{r}_{\text {table }}$ & Description \\
\hline X1.1 & 0,598 & 0,191 & Valid \\
X1.2 & 0,667 & 0,191 & Valid \\
X1.3 & 0,764 & 0,191 & Valid \\
X1.4 & 0,392 & 0,191 & Valid \\
X2.1 & 0,764 & 0,191 & Valid \\
X2.2 & 0,793 & 0,191 & Valid \\
X2.3 & 0,509 & 0,191 & Valid \\
X2.4 & 0,562 & 0,191 & Valid \\
X3.1 & 0,732 & 0,191 & Valid \\
X3.2 & 0,487 & 0,191 & Valid \\
X3.3 & 0,793 & 0,191 & Valid \\
X3.4 & 0,802 & 0,191 & Valid \\
X3.5 & 0,763 & 0,191 & Valid \\
X4.1 & 0,791 & 0,191 & Valid \\
X4.2 & 0,789 & 0,191 & Valid \\
X4.3 & 0,748 & 0,191 & Valid \\
X4.4 & 0,837 & 0,191 & Valid \\
Y1 & 0,799 & 0,191 & Valid \\
Y2 & 0,713 & 0,191 & Valid \\
Y3 & 0,839 & 0,191 & Valid \\
Y4 & 0,794 & 0,191 & Valid \\
Y5 & 0,759 & 0,191 & Valid \\
\hline
\end{tabular}

Multiple linear regression was performed to test all of the hypotheses on the four independent variables (environmental concern, green perceived value, subjective norms, and green trust) towards green purchase intention (dependent variable). The result of this regression was shown in Table 3. As highlighted in Table 3, the overall result for the regression model was significant (Significance $=0.000$ ). It indicated that all the factors (environmental concern, green perceived value, subjective norms, and green trust were simultaneously significant to the dependent variable (green purchase intention). From the 
adjusted $\mathrm{R}$ square value (Adjusted $\mathrm{R}$ Square $=0.719$ ), the three four contributed $71.9 \%$ to the dimension of green purchase intention.

Table 2. Result of Reliability Test

\begin{tabular}{lcc}
\hline \multicolumn{1}{c}{ Statement Variable Items } & $\begin{array}{c}\text { Cronbach's } \\
\text { Alpha }\end{array}$ & Description \\
\hline Environmental Concern $\left(\mathrm{X}_{1}\right)$ & 0,789 & Reliable \\
Subjective Norm $\left(\mathrm{X}_{2}\right)$ & 0,826 & Reliable \\
Green perceived value $\left(\mathrm{X}_{3}\right)$ & 0,875 & Reliable \\
Green trust $\left(\mathrm{X}_{4}\right)$ & 0,906 & Reliable \\
Green Purchase Intention $(\mathrm{Y})$ & 0,910 & Reliable \\
\hline
\end{tabular}

Table 3. Result of Regression Analysis

\begin{tabular}{|c|c|c|c|}
\hline \multicolumn{4}{|c|}{ Dependent Variable: Green Purchase Intention } \\
\hline & $\begin{array}{c}\text { Standardized } \\
\text { Coefficient (beta) }\end{array}$ & $\mathrm{t}$-value & Significance \\
\hline Constant & & 0.396 & 0.693 \\
\hline $\begin{array}{l}\text { Environmental } \\
\text { Concern }\end{array}$ & 0.113 & 2.020 & 0.046 \\
\hline Subjective Norm & 0.203 & 3.413 & 0.001 \\
\hline $\begin{array}{c}\text { Green perceived } \\
\text { value }\end{array}$ & 0.343 & 3.983 & 0.000 \\
\hline Green trust & 0.388 & 4.580 & 0.000 \\
\hline & $\begin{aligned} \text { R Square } & =0.73 \\
d R \text { Square } & =0.71\end{aligned}$ & $\begin{array}{l}=68 . \\
\text { ance }=\end{array}$ & \\
\hline
\end{tabular}

From the analysis, all of the factors contribute significantly to green purchase intention. The result could be seen by seeing the significance of each factor which should be $<0.005$. Factor 1 which is environment concern (significant value $=0.046,<0.05$ ), factor 2 which is Subjective norm (significant value $=0.001,<0.05$ ), factor 3 which is green perceived value (significant value $=0.000,<0.05$ ), factor 4 which is green trust (significant value $=0.000,<0.05$ ). The results of standardized coefficient (beta) revealed that factor 4 (green trust) was the most important variable that contributed to the dependent variable (beta $=0.388$ ). The results of tolerance and VIF value for each factor were displayed in Table 4. Each factor tested the different dimensions clearly and without any multicollinearity problem as indicated with the tolerance rate of more than 0.1 and VIF $<10$ (Hair et al, 1998).

Through the testing of hypothesis 1 , it is discovered that environmental awareness has a significant and positive influence on purchase intention in green products. This shows that the more an individual are concerned about the environment, it will increase the interest in purchasing green products as a form of consumer care to protect the environment. So, it can be concluded that hypothesis 1 which states that environmental 
concern has a significant and positive effect on the purchase intention of green products is acceptable and it can answer the research questions that have been raised regarding whether environmental concern has a significant direct effect on purchase intention on green products.

Table 4. Collinearity Statistics (tolerance and VIF value)

\begin{tabular}{ccc}
\hline & Tolerance & VIF \\
\hline Environmental Concern & 0.858 & 1.165 \\
Subjective Norm & 0.757 & 1.321 \\
Green perceived value & 0.361 & 2.773 \\
Green trust & 0.374 & 2.677 \\
\hline
\end{tabular}

Through the testing of hypothesis 2, it is revealed that Subjective Norm has significant and positive influence on purchase intention in green products. This shows that consumers are influenced to buy green products with the influence of relatives and important individuals in their lives. Then it can be concluded that hypothesis 2 which states that Subjective Norm has a significant and positive effect on purchase intention in green products is acceptable and can answer the research questions that have been raised about whether the perception of Subjective norm has a significant direct effect on purchase intention in Green Hotels.

Through testing hypothesis 3, it is discovered that Green Perceived Value has a significant and positive effect on purchase intention in green hotels. This shows that consumers do feel the benefits and satisfaction of environmentally friendly products, consumers will be aware and have the desire to buy environmentally friendly services. Then it can be concluded that hypothesis 3 which states that Green Perceived Value has a significant and positive effect on buying interest in green service is accepted and could answer the research questions that have been raised about whether Green Perceived Value has a significant direct effect on purchase intention in Green Hotels.

Through testing hypothesis 4, it is known that Green Trust has a significant and positive effect on buying interest in green service. This shows that consumers are willing to give their trust in an environmentally friendly product or service. Then it can be concluded that hypothesis 4 which states that Green Trust has a significant and positive effect on purchase intention in green services is accepted and can answer research questions that have been raised about whether Green Trust has a significant direct effect on purchase intention in Green Hotels.

\section{CONCLUSIONS AND SUGGESTIONS}

Based on the results of the research related to consumers regarding the state of the environment, social conditions, and knowledge about Green Hotels, it could be concluded that students from upper-middle class families in Indonesia care about the environment and tend to want to improve or protect the environment so that it will be 
better in the future, they are of the view that by using green services or green products they can save the earth's health in the future. Therefore, it is suggested for companies, especially those which still insist of using conventional hotel system, to switch to green hotels because in the future most consumers from middle- and upper-class families, including younger generation who will take over economic activities in the future, prefer to stay at green hotels compared to conventional hotels for environmental reasons. It is also hoped that the company will provide a more detailed explanation of the current environmental issues by conducting promotions which at the same time provide education to the wider community.

Through the analysis conducted in this study, it is found several limitations of the research in the preparation process. This research can only represent Indonesian respondents because it is done in a city and this could not generalize the results of this study for the worldwide usage. In the future, the author suggests to increase the number of samples and respondents used so as to obtain representative research results that are able to describe the condition of the population more broadly. It is also hoped that the coverage in the research area will further be expanded and extended to the age category and also to social classes of respondent.

In this study, researchers used several independent variables (Environmental Awareness, Subjective Norm, Green Perceived Value and Green Trust). In the future studies, it is hoped that future researchers could make modifications by adding new variables such as price, willingness to pay, etc. which are considered to be able to increase the influence of more diverse independent variables and then turn it into a company resolution to find out about the consumers purchase intention regarding green services.

\section{REFERENCES}

Ajzen, I. (1991). The theory of planned behavior. Organizational Behavior and Human Decision Processes. https://doi.org/10.1016/0749-5978(91)90020-T

Bolton, R. N., \& Drew, J. H. (1991). A Multistage Model of Customers' Assessments of Service Quality and Value. Journal of Consumer Research. https://doi.org/10.1086/208564

Buckley, H., Depraz, S., \& O’Neal, A. (2007). Oil and gas industry guidance on voluntary sustainability reporting. Society of Petroleum Engineers - Asia Pacific Health, Safety, Security and Environment Conference and Exhibition 2007 - "Responsible Performance: Are We Doing the Best We Can." https://doi.org/10.2523/98585-ms

Elsa, \& Alamsyah, D. P. (2013). Pengaruh Citra Merek dan Pandangan Kualitas Terhadap Kepercayaan Konsumen Pada McDonald's Bandung. Ecodemica. 
Eze, U. C., \& Ndubisi, N. O. (2013). Green Buyer Behavior: Evidence from Asia Consumers. Journal of Asian and African Studies, 48(4), 413-426. https://doi.org/10.1177/0021909613493602

Gurău, C., \& Ranchhod, A. (2005). International green marketing: A comparative study of British and Romanian firms. International Marketing Review. https://doi.org/10.1108/02651330510624381

Heijden, H. Van Der, Verhagen, T., \& Creemers, M. (2003). Understanding online purchase intentions: Contributions from technology and trust perspectives. European Journal of Information Systems. https://doi.org/10.1057/palgrave.ejis.3000445

Hsu, C. L., \& Lin, J. C. C. (2015). What drives purchase intention for paid mobile apps?An expectation confirmation model with perceived value. Electronic Commerce Research and Applications. https://doi.org/10.1016/j.elerap.2014.11.003

Jiang, Y., \& Kim, Y. (2015). Developing multi-dimensional green value extending social exchange theory to explore customers' purchase intention in green hotels-evidence from Korea. International Journal of Contemporary Hospitality Management, 27(2), 308-334. https://doi.org/10.1108/IJCHM-08-2013-0383

Kim, H. Y., \& Chung, J. E. (2011). Consumer purchase intention for organic personal care products. Journal of Consumer Marketing. https://doi.org/10.1108/07363761111101930

Kim, Yeonshin. (2015). Antecedents of green purchase behavior: An examination of collectivism, environmental concern, and PCE Antecedents of Green Purchase Behavior: An Examination of Collectivism, Environmental. July.

Kim, Yunhi, \& Han, H. (2010). Intention to pay conventional-hotel prices at a green hotel - a modification of the theory of planned behavior. Journal of Sustainable Tourism. https://doi.org/10.1080/09669582.2010.490300

Laroche, M., Bergeron, J., \& Barbaro-Forleo, G. (2001). Targeting consumers who are willing to pay more for environmentally friendly products. Journal of Consumer Marketing, 18(6), 503-520. https://doi.org/10.1108/EUM0000000006155

Mohd Suki, N. (2016). Green product purchase intention: impact of green brands, attitude, and knowledge. British Food Journal. https://doi.org/10.1108/BFJ-06-2016-0295

Ostrom, A. L., Bitner, M. J., Brown, S. W., Burkhard, K. A., Goul, M., Smith-Daniels, V., Demirkan, H., \& Rabinovich, E. (2010). Moving forward and making a difference: 
Research priorities for the science of service. Journal of Service Research. https://doi.org/10.1177/1094670509357611

Patterson, P. G., \& Spreng, R. A. (1997). Modelling the relationship between perceived value, satisfaction and repurchase intentions in a business-to-business, services context: An empirical examination. International Journal of Service Industry Management. https://doi.org/10.1108/09564239710189835

Schepers, J., \& Wetzels, M. (2007). A meta-analysis of the technology acceptance model: Investigating subjective norm and moderation effects. Information and Management. https://doi.org/10.1016/j.im.2006.10.007

Schlosser, A. E., White, T. B., \& Lloyd, S. M. (2006). Converting web site visitors into buyers: How web site investment increases consumer trusting beliefs and online purchase intentions. Journal of Marketing. https://doi.org/10.1509/jmkg.70.2.133

Shimp, T. A., \& Kavas, A. (1984). The Theory of Reasoned Action Applied to Coupon Usage. Journal of Consumer Research. https://doi.org/10.1086/209015

Shireman, B., \& Kiuchi, T. (2002). Doing business like a rainforest: Feedback and closedloop systems. Environmental Quality Management, 12(1), 9-17. https://doi.org/10.1002/tqem.10049

Tarkiainen, A., \& Sundqvist, S. (2005). Subjective norms, attitudes and intentions of Finnish consumers in buying organic food. British Food Journal. https://doi.org/10.1108/00070700510629760

Teng, C. C., Lu, A. C. C., \& Huang, T. T. (2018). Drivers of consumers' behavioral intention toward green hotels. International Journal of Contemporary Hospitality Management. https://doi.org/10.1108/IJCHM-04-2017-0203

ZeithamI, V. A. (1988). Consumer Perceptions of Price, Quality, and Value: A Means-End Model and Synthesis of Evidence. Journal of Marketing. https://doi.org/10.2307/1251446 